\title{
Growth, Nutrient Uptake, and Yield Promotion of Broccoli by Plant Growth Promoting Rhizobacteria with Manure
}

\author{
Ertan Yildirim \\ Atatürk University, Faculty of Agriculture, Department of Horticulture, \\ 25240 Erzurum, Turkey
}

Huseyin Karlidag

Inonu University, Faculty of Agriculture, Department of Horticulture, 44280

Malatya, Turkey

\author{
Metin Turan \\ Atatürk University, Faculty of Agriculture, Department of Soil Science, \\ 25240 Erzurum, Turkey
}

Atilla Dursun

Atatürk University, Faculty of Agriculture, Department of Horticulture, 25240 Erzurum, Turkey

\section{Fahrettin Goktepe ${ }^{1}$}

Crop Science 109, Oregon State University, Corvallis, OR 97331-3002

Additional index words. bacterial inoculation, broccoli, fertilizer use efficiency, nutrient uptake, plant growth, yield

\begin{abstract}
This study was conducted to investigate the effects of root inoculations with Bacillus cereus ( $\mathrm{N}_{2}$-fixing), Brevibacillus reuszeri (P-solubilizing), and Rhizobium rubi (both $\mathrm{N}_{\mathbf{2}}$-fixing and P-solubilizing) on plant growth, nutrient uptake, and yield of broccoli in comparison with manure (control) and mineral fertilizer application under field conditions in 2009 and 2010. Bacterial inoculations with manure compared with control significantly increased yield, plant weight, head diameter, chlorophyll content, nitrogen $(\mathrm{N})$, potassium $(\mathrm{K})$, calcium $(\mathrm{Ca})$, sulfur $(\mathrm{S})$, phosphorus $(\mathrm{P})$, magnesium $(\mathrm{Mg})$, iron $(\mathrm{Fe})$, manganese $(\mathrm{Mn})$, zinc $(\mathrm{Zn})$, and copper $(\mathrm{Cu})$ content of broccoli. The lowest yield per plant, plant weight, steam diameter, and chlorophyll content were recorded in the control, but the manure with Bacillus cereus (BC), Rhizobium rubi (RR), and Brevibacillus reuszeri (BR) inoculations increased yield $17.0 \%, 20.2 \%$, and $24.3 \%$ and chlorophyll content by $14.7 \%, 14.0 \%$, and $13.7 \%$ over control, respectively. Bacterial inoculations with manure significantly increased uptake of macronutrients and micronutrients by broccoli. In conclusion, seedling inoculation with BR and especially RR may partially substitute costly synthetic fertilizers in broccoli.
\end{abstract}

Many agricultural soils of the world are deficient in one or more of the essential nutrients needed to support healthy plants. Acidity, alkalinity, salinity, anthropogenic processes, and erosion can lead to soil degradation. Addition of fertilizers and/or amendments is essential for a proper nutrient supply and maximum yields. Chemical fertilizers often have low use efficiency, meaning that only a portion of

\footnotetext{
Received for publication 18 Feb. 2011. Accepted for publication 2 May 2011

We thank Ataturk University for generous financial support and Ramazan Cakmakci of the Field Crops Department, Agricultural Faculty, Ataturk University, for his technical assistance and supplying bacterial strains.

${ }^{1}$ To whom reprint requests should be addressed; e-mail Fahrettin.Goktepe@oregonstate.edu.
}

the applied nutrients is taken up by plants (Adesemoye et al., 2009). Estimates of overall efficiency of applied fertilizer have been reported to be about or lower than $50 \%$ for $\mathrm{N}$, less than $10 \%$ for $\mathrm{P}$, and $\approx 40 \%$ for $\mathrm{K}$ in mineral fertilizer and are lower in manure. Plants that efficiently absorb and use nutrients greatly enhance the overall efficiency of applied fertilizers, reducing cost of inputs and preventing loss of nutrients to ecosystems (Baligar et al., 2001).

Fertilizer use efficiency can be optimized by fertilizer management practices that apply nutrients at the right rate, time, and place in both conventional and organic farming. There must be a balance between optimal nutrient use efficiency and optimal crop productivity (Roberts, 2008). Intensive farming practices, which demand high yield and quality, require extensive use of chemical fertilizers, which are costly and can create environmental problems. The use of chemical fertilizers to enhance soil fertility and crop productivity has often negatively affected the complex system of biogeochemical cycles. For example, fertilizer use has caused leaching and runoff of nutrients, especially $\mathrm{N}$ and $\mathrm{P}$, leading to environmental degradation. Therefore, interest has grown in environmentally sustainable and organic agricultural practices (Esitken et al., 2005).

One potential way to decrease negative environmental impacts resulting from inefficient use of chemical fertilizers is inoculation with plant growth promoting rhizobacteria (PGPR). These bacteria exert beneficial effects on plant growth and development and therefore may be used as biofertilizers for agriculture (Adesemoye et al., 2009). So far numerous bacterial species, mostly associated with the plant rhizosphere, have been tested and found to be beneficial for plant growth, yield, and crop quality. They have been called PGPR including the strains in the genera Acinetobacter, Alcaligenes, Arthrobacter, Azospirillium, Azotobacter, Bacillus, Beijerinckia, Burkholderia, Enterobacter, Erwinia, Flavobacterium, Rhizobium, and Serratia (Bashan and de-Bashan, 2005; Han and Lee, 2005). Capabilities of PGPR range from enhancing yields of organic systems to pollution control. Success of PGPR in organic systems is attributed to more rapid breakdown of organic matter, enhanced availability of nutrients, and improved soil properties, and these effects are mostly explained by the release of metabolites directly stimulating growth. All the mechanisms by which PGPR promote plant growth are not fully understood but may include the ability to produce plant hormones such as auxins, cytokinins, gibberellins, and inhibit ethylene production; a symbiotic $\mathrm{N}_{2}$ fixation; solubilization of inorganic phosphate and mineralization of organic phosphate and/or other nutrients; antagonism against phytopathogenic microorganisms by production of siderophores; the synthesis of antibiotics, enzymes, and/or fungicidal compounds; and competition with detrimental microorganisms (Caballero-Mellado et al., 2007).

A principal problem of organic farming is the low nutrient status of most organic fertilizers (Mengel and Kirkby, 1987). Nutrient content of organic fertilizers varies widely depending on the source and moisture content. This problem is further compounded by the difficulties in assessing the value of organic fertilizers through direct analysis of total quantities of plant nutrients. Thus, field experiments are needed to determine the nutrient availability and efficiency of most organic fertilizers. This is the result of the slow and variable release rates of nutrients during decomposition of organic materials (Hsieh and Hsieh, 1990). Biofertilizers with PGPR can be used to increase soil productivity and plant growth in sustainable agriculture through increasing mineral and organic fertilizer use efficiency (Adesemoye et al., 2009). 
Most studies with PGPR were carried out to determine direct beneficial effects on plant growth but lack information about the effect of PGPR on organic fertilizer use efficiency in plant growth. Therefore, a study was conducted to investigate the effects of PGPR inoculations with manure on plant growth parameters, nutrient uptake, and yield of broccoli in comparison with mineral fertilizer application under field conditions.

\section{Materials and Methods}

Plant material. Broccoli 'Monet F1' (Brassica oleracea L., var. italica) plants, middle season variety, as plant material was used.

Field experiments. Field trials were conducted in Experimental Farm of Ataturk University in Erzurum in Eastern Anatolia (lat. $29^{\circ} 55^{\prime} \mathrm{N}$; long. $41^{\circ} 16^{\prime} \mathrm{E}$; altitude $1850 \mathrm{~m}$ ), Turkey, in 2009 and 2010. The soil at the experimental area had $28.3 \%$ sand, $32.2 \%$ silt, and $39.5 \%$ clay. Relevant soil chemical characteristics were as follows: soil $\mathrm{pH} 7.3$; organic matter 3.5\%; $\mathrm{P} ; 0.9 \mathrm{mg} \mathrm{P}_{2} \mathrm{O}_{5}$ per $100 \mathrm{~g}$ soil and $\mathrm{K} 123 \mathrm{mg} \mathrm{K} \mathrm{K}_{2} \mathrm{O}$ per $100 \mathrm{~g}$ soil. Approximately $30 \mathrm{t} \cdot \mathrm{ha}^{-1}$ manure, which contained $2.4 \% \mathrm{~N}$, $1.8 \% \mathrm{~K}_{2} \mathrm{O}, 2.1 \% \mathrm{P}_{2} \mathrm{O}_{5}$, and electrical conductivity (EC) of $6.3 \mathrm{dS} \cdot \mathrm{m}^{-1}$, was applied to the beds before planting. With an average temperature of $5.7^{\circ} \mathrm{C}$ and total rainfall of $402.5 \mathrm{~mm}$ (Table 1), plant growth in the region is restricted to the period between May and October. The second year of the experiment received higher and more even distribution of rainfall in the growing months of May, July, and August, whereas average monthly air and soil temperatures were generally higher in the first year of the experiment (Table 1). Average daily air temperature ranged between 8.6 and $28.3^{\circ} \mathrm{C}$ in the growing season of 2009 and between 11.2 and $22.6{ }^{\circ} \mathrm{C}$ in the growing season of 2010 . Average daily soil temperafirst growing season and between 13.7 and $24.3^{\circ} \mathrm{C}$ in the second growing season (Table 1).

Broccoli seeds were sown into plastic trays filled with peat (pH: $5.5, \mathrm{EC}: 250 \mathrm{dS} \cdot \mathrm{m}^{-1}, \mathrm{~N}$ : $300 \mathrm{mg} \cdot \mathrm{L}^{-1}$, P: $131 \mathrm{mg} \cdot \mathrm{L}^{-1}, \mathrm{~K}: 333.33 \mathrm{mg} \cdot \mathrm{L}^{-1}$, organic matter: $2 \%$ ). Seedlings were initially grown in a greenhouse and then transplanted after $\approx 1$ month in rows $(0.50 \mathrm{~m}$ apart with intrarow spacing of $0.45 \mathrm{~m}$ ) in late June in both years. Each plot consisted of 25 plants. Treatments consisted of 1) control (manure +100 $\mathrm{kg} \cdot \mathrm{ha}^{-1}$ rock phosphate including $18 \% \mathrm{P}_{2} \mathrm{O}_{5}$ organic); 2) mineral fertilizer (N $120 \mathrm{~kg} \cdot \mathrm{ha}^{-1}$ as urea and $\mathrm{P} 180 \mathrm{~kg} \mathrm{P}_{2} \mathrm{O}_{5} /$ ha as triple superphosphate $48 \% \mathrm{P}_{2} \mathrm{O}_{5}$ ); 3) $\mathrm{BC}$ (manure + rock ture ranged between 14.4 and $24.8^{\circ} \mathrm{C}$ in the

phosphate + Bacillus cereus); 4) BR (manure + rock phosphate + Brevibacillus reuszeri); and 5) RR (manure + rock phosphate + Rhizobium rubi). Marketable broccoli heads were harvested in September in both years. Inner rows were used for sampling and harvest. Entire plants were harvested at ground level and weighed from each plot when the terminal buds were swollen but not opened. Stem diameter was measured from the ground level. Plants were then cut $20 \mathrm{~cm}$ below the top of head, which was trimmed to obtain a marketable product. Head diameter was measured across the widest part of the head. The plant materials were weighed for leaf and head dry matter ratio and then dried in an oven at $70{ }^{\circ} \mathrm{C}$ until a constant mass was reached.

Chlorophyll readings. A portable chlorophyll meter (SPAD-502; Konica Minolta Sensing, Inc., Japan) was used to measure leaf greenness. SPAD-502 chlorophyll meter estimates total chlorophyll amounts in leaves in a non-destructive method (Neufeld et al., 2006). For each plant, measurements were taken at four locations on each leaf, two on each side of the midrib on all fully expanded leaves (Khan et al., 2003), and the same leaves were used for chemical analyses (Alcantar et al., 2002).

Bacterial strains, culture conditions, media, and treatment. Bacterial strains were originally isolated from the rhizosphere of tea plants naturally grown in Rize, Turkey, and identified as Bacillus cereus, Brevibacillus reuszeri, and Rhizobium rubi based on fatty acid methyl ester analysis using the MIDI system (Sherlock Microbial Identification System Version 4.5; MIDI, Inc., Newark, $\mathrm{DE})$. For this experiment, the bacterial strains were grown on nutrient agar. A single colony was transferred to $250-\mathrm{mL}$ flasks containing NB and grown aerobically in flasks on a rotating shaker $(95 \mathrm{rpm})$ for $24 \mathrm{~h}$ at $27^{\circ} \mathrm{C}$. The bacterial suspension was then diluted in sterile distilled water to a final concentration of $10^{8}$ colony-forming units (cfu) $/ \mathrm{mL}$. Bacterial suspensions were measured and concentration of bacterial population arranged to the desired level $\left(10^{8} \mathrm{cfu} / \mathrm{mL}\right)$ using a spectrophotometer at $630 \mathrm{~nm}$ (a ultraviolet/VIS Aqumat spectrophotometer; Thermo Electron Spectroscopy Ltd., Cambridge, U.K.) (AOAC, 2005). Bacterial applications of Bacillus cereus, Brevibacillus reuszeri, and Rhizobium rubi were performed using a dipping method in which seedling roots were inoculated with the bacterial suspensions at the concentration of $10^{8} \mathrm{cfu} / \mathrm{mL}$ in sterile water $\approx 60 \mathrm{~min}$ before transplanting. Control plants were dipped into sterile water. The

Table 1. Climatic data on the experimental site.

\begin{tabular}{ccccccccc}
\hline & & & & & & & \multicolumn{2}{c}{ Total/avg } \\
\cline { 3 - 8 } Climatic factors & Years & May & June & July & August & September & Growth season & Annual \\
\hline Total rainfall & $1985-2010$ & 70.5 & 47.9 & 27.4 & 17.1 & 24.4 & 187.3 & 402.5 \\
$(\mathrm{~mm})$ & 2009 & 41.6 & 72.2 & 20.7 & 3.5 & 29.2 & 167.2 & 367.4 \\
& 2010 & 58.3 & 61.8 & 41.9 & 30.4 & 0.1 & 192.5 & 488.8 \\
Average air & $1985-2010$ & 10.6 & 14.9 & 19.3 & 19.4 & 14.7 & 15.8 & 5.7 \\
temperature & 2009 & 11.4 & 18.4 & 20.3 & 22.6 & 14.1 & 17.4 & 6.4 \\
$\left({ }^{\circ} \mathrm{C}\right)$ & 2010 & 12.8 & 14.4 & 18.1 & 18.6 & 15.2 & 15.8 & 5.5 \\
\hline
\end{tabular}

bacterial strains Bacillus cereus and Rhizobium rubi were able to grow in $\mathrm{N}$-free basal medium indicating its N-fixing potential. In the present study, P-solubilizing activities of Brevibacillus reuszeri and Rhizobium rubi were measured according to the qualitative methods (Mehta and Nautiyal, 2001).

Mineral analysis. At heading is a good time to assess the relationship between broccoli nutrient content and soil nutrient pools (Jones et al., 1991; Mengel and Kirkby, 2001). Therefore, tissue subsamples were taken during heading (five youngest leaves), then ovendried at $68^{\circ} \mathrm{C}$ for $48 \mathrm{~h}$ and ground, and passed a 1-mm sieve size. The Kjeldahl method and a Vapodest 10 Rapid Kjeldahl Distillation Unit (Gerhardt, Konigswinter, Germany) were used to determine total N (Bremner, 1996). Macro- [P, K, S, Ca, Mg, and sodium (Na)] and microelements ( $\mathrm{Fe}, \mathrm{Mn}, \mathrm{Zn}$, and $\mathrm{Cu}$ ) were determined after wet digestion of dried and ground subsamples using a $\mathrm{HNO}_{3}-\mathrm{H}_{2} \mathrm{O}_{2}$ acid mixture $(2: 3 \mathrm{v} / \mathrm{v})$ with three steps [first step; $145{ }^{\circ} \mathrm{C}, 75 \%$ radio-frequecy power (RF), 5 min; second step; $180{ }^{\circ} \mathrm{C}, 90 \% \mathrm{RF}, 10 \mathrm{~min}$; and third step; $\left.100{ }^{\circ} \mathrm{C}, 40 \% \mathrm{RF}, 10 \mathrm{~min}\right]$ in microwave digestion (Bergof Speedwave Microwave Digestion Equipment MWS-2; Berghof Products and Instruments, Eningen, Germany) (Mertens, 2005a). Tissue P, K, S, $\mathrm{Ca}, \mathrm{Mg}, \mathrm{Na}, \mathrm{Fe}, \mathrm{Mn}, \mathrm{Zn}$, and $\mathrm{Cu}$ were determined using an inductively coupled plasma spectrophotometer (Optima 2100 DV, ICP/OES; Perkin-Elmer, Shelton, CT) (Mertens, 2005b).

Data analysis. Experiments were repeated in 2 years. Each experiment consisted of a randomized complete block experimental design with three blocks. All data in the present study were subjected to analysis of variance using SPSS 18 (PASW Statistics 18) (SPSS Inc., 2010) statistical program. Means were separated by Duncan's multiple range tests. There were no significant interactions by year; therefore, the data were pooled.

\section{Results}

Effects of bacterial treatments on broccoli yield and growth parameters. There were no significant interactions for effects across years for the characteristics investigated. Across 2 years, bacterial treatments increased head yield per plant, plant weight, stem diameter, head diameter, and chlorophyll reading values but not head dry matter ratio or leaf dry matter ratio of broccoli in this study compared with control (Table 2).

Lowest head yield per plant, plant weight, stem diameter, head diameter, and chlorophyll reading values were recorded in the control. Highest head yield per plant, plant weight, stem diameter, head diameter, and chlorophyll reading values were obtained from mineral fertilizer and RR inoculations with manure application. Relative yield, which is the broccoli yield expressed as percentage of the highest yield obtained from mineral fertilizer application, was the $76.5 \%$ for control, $89.5 \%$ for $\mathrm{BC}, 92.4 \%$ for $\mathrm{BR}$, and $95.1 \%$ for $\mathrm{RR}$ treatments (Fig. 1). On the other hand, BC, 
Table 2. Effects of plant growth promoting rhizobacteria applications on plant yield, yield parameters, and total chlorophyll content of broccoli plant.

\begin{tabular}{lccccc}
\hline & Mineral & Organic & Organic + BC & Organic + BR & Organic + RR \\
\hline Yield per plant $(\mathrm{g})$ & $801 \mathrm{a}^{\mathrm{z}}$ & $613 \mathrm{c}$ & $717 \mathrm{~b}$ & $740 \mathrm{ab}$ & $762 \mathrm{ab}$ \\
Plant weight per plant $(\mathrm{g})$ & $2324 \mathrm{a}$ & $1877 \mathrm{~b}$ & $2208 \mathrm{a}$ & $2202 \mathrm{a}$ & $2416 \mathrm{a}$ \\
Stem diameter $(\mathrm{cm})$ & $2.71 \mathrm{a}$ & $2.41 \mathrm{~b}$ & $2.38 \mathrm{~b}$ & $2.60 \mathrm{ab}$ & $2.59 \mathrm{ab}$ \\
Head diameter $(\mathrm{cm})$ & $13.86 \mathrm{a}$ & $12.02 \mathrm{~b}$ & $12.75 \mathrm{ab}$ & $12.54 \mathrm{ab}$ & $13.98 \mathrm{a}$ \\
Chlorophyll content & $74.16 \mathrm{ab}$ & $69.58 \mathrm{~b}$ & $79.71 \mathrm{a}$ & $78.59 \mathrm{a}$ & $77.96 \mathrm{a}$ \\
Head dry matter ratio (\%) & $11.80 \mathrm{NS}$ & 13.04 & 13.22 & 12.55 & 11.84 \\
Leaf dry matter ratio (\%) & $15.48 \mathrm{~b}$ & $16.03 \mathrm{a}$ & $15.25 \mathrm{bc}$ & $14.93 \mathrm{c}$ & $15.54 \mathrm{~b}$ \\
\hline
\end{tabular}

${ }^{\mathrm{z}}$ Mean values in lines followed by a different letters differ significantly at $P<0.05$. NS $=$ Non-significant.
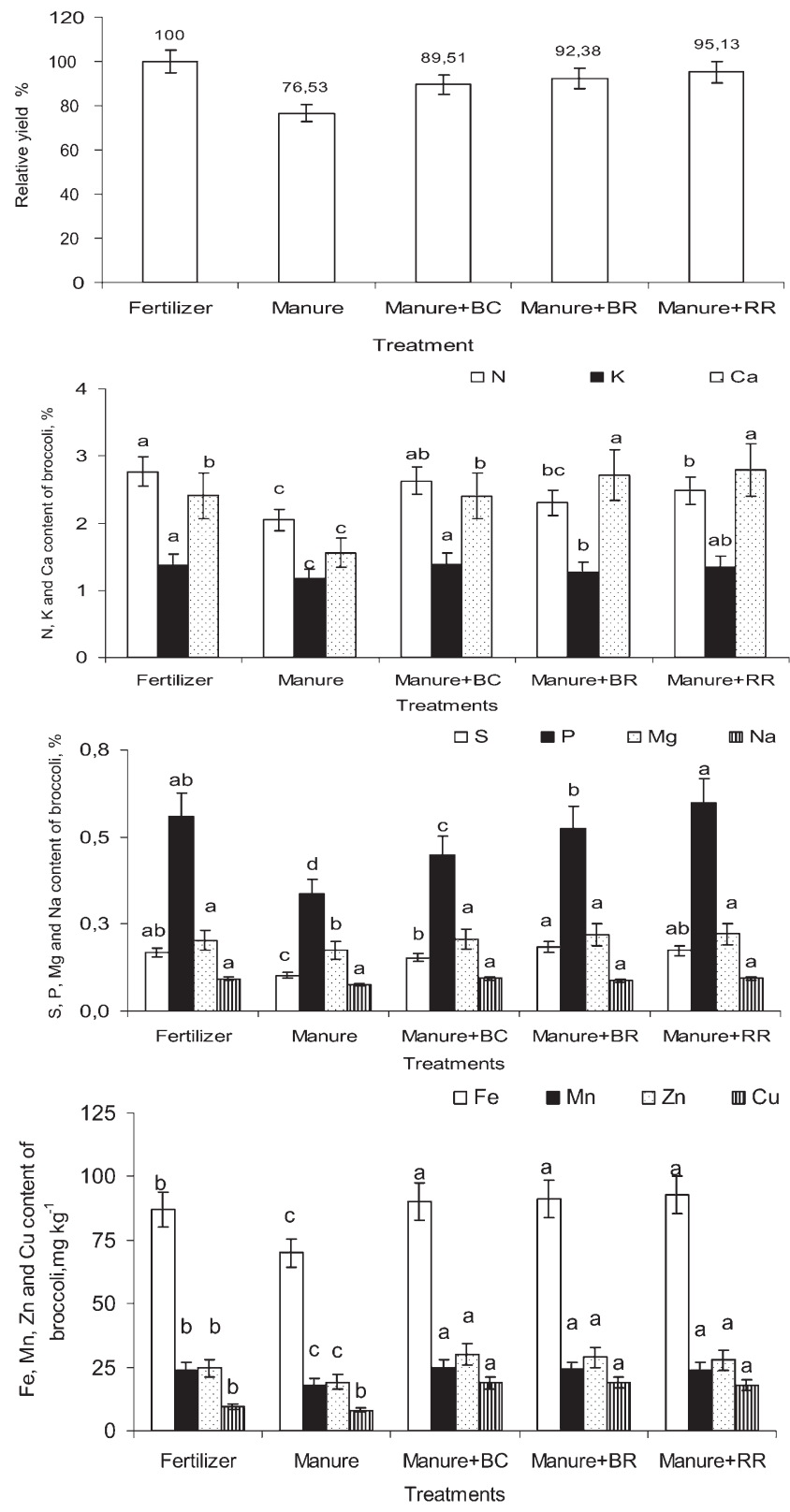

Fig. 1. Relative yield; nitrogen $(\mathrm{N})$, potassium $(\mathrm{K})$, calcium $(\mathrm{Ca})$, sulfur $(\mathrm{S})$, phosphorus $(\mathrm{P})$, magnesium $(\mathrm{Mg})$, sodium $(\mathrm{Na})$, iron $(\mathrm{Fe})$, manganese $(\mathrm{Mn})$, zinc $(\mathrm{Zn})$, and copper $(\mathrm{Cu})$ content of broccoli in response to plant growth promoting rhizobacteria (PGPR) applications. Different letters on top of bars indicate differences $(P<0.05)$. Vertical bars indicate the mean $\pm \mathrm{SE}$.

$\mathrm{BR}$, and RR inoculations with manure application increased $17 \%, 20 \%$, and $24 \%$ in yield per plant and $17 \%, 17 \%$, and $29 \%$ in plant weight compared with control (Table 2), respectively. The positive effect recorded for the with the control. BC, BR, and RR inoculations with manure application increased $14 \%$, $14 \%$, and $13 \%$ in chlorophyll compared with control, respectively (Table 2). SPAD chlorophyll values of broccoli leaves were correlated with tissue total $\mathrm{N}$ concentrations from the laboratory analysis, which means that chlorophyll values increased values with PGPR treatments (Table 2; Fig. 1).

Effects of biofertilizer on plant nutrient element content. Results showed bacterial inoculations significantly affected ionic compositions of plant leaves (Fig. 1). In this study, the data demonstrated that bacterial applications increased $\mathrm{N}, \mathrm{P}, \mathrm{K}, \mathrm{Ca}, \mathrm{Mg}, \mathrm{S}, \mathrm{Fe}$, $\mathrm{Mn}, \mathrm{Zn}$, and $\mathrm{Cu}$ contents of leaves compared with the control.

$\mathrm{N}_{2}$-fixing and P-solubilizing PGPR strains promoted plant nutrient element (PNE) contents of leaves of the plant. Although mineral fertilizer had the highest $\mathrm{N}$ content of leaves, $\mathrm{BC}$ with manure had the highest $\mathrm{K}, \mathrm{Mn}$, and $\mathrm{Zn}$; BR with manure had the highest $\mathrm{S}$ and $\mathrm{Cu}$; and $\mathrm{RR}$ with manure had the highest $\mathrm{Ca}$, $\mathrm{P}, \mathrm{Mg}$, and $\mathrm{Fe}$ (Fig. 1). Leaf nutrient content for $\mathrm{K}, \mathrm{Mn}$, and $\mathrm{Zn}$ increased $18.6 \%, 36.4 \%$, and $56.7 \%$ for $\mathrm{BC}$ with manure; $\mathrm{S}$ and $\mathrm{Cu}$ contents of leaves increased $78.5 \%$ and $134 \%$ for $\mathrm{BR}$ with manure; and $\mathrm{Ca}, \mathrm{P}, \mathrm{Mg}$, and $\mathrm{Fe}$ contents of leaves increased $78.8 \%, 76.7 \%$, $26.5 \%$, and $22.9 \%$ for RR inoculations with manure application compared with control, respectively (Fig. 1).

\section{Discussion}

This is the first study to demonstrate that PGPR root inoculation with manure can increase yield, growth, and PNE contents of broccoli plants. Two years of trials under field conditions showed that inoculations with $B a$ cillus cereus, Brevibacillus reuszeri, and Rhizobium rubi significantly increased yield, yield parameters, and PNE uptake of broccoli. However, the strain $B$. cereus is a member of potential pathogens in risk Group 2, so we could not suggest using it as a biofertilizer in every condition. Bacterial applications with manure positively affected head yield per plant, plant weight, stem diameter, head diameter, and chlorophyll reading compared with the control; and RR was the most effective PGPR in the treatment. The yield and plant growth enhancement effects of bacteria used in this study on broccoli could be explained with the $\mathrm{N}_{2}$-fixing and P-solubilizing capacity of bacteria. The effects of a combined treatment of PGPR (mixture of Bacillus sp., B. subtillis, $B$ erythropolis, B. pumilus, and $P$. rubiacearum $)$ plus $50 \%$ chemical fertilizer $(1 / 2 \mathrm{CF}+$ biofertilizer) on the growth of lettuce were compared by Young et al. (2003). Results showed there was a $25 \%$ increase of lettuce yield for the treatment of $1 / 2 \mathrm{CF}+$ biofertilizer compared with that of the CF treatment, indicating that at least $50 \%$ of chemical fertilizer can be saved as a multifunctional biofertilizer was used along with a chemical fertilizer.

Young et al. (2004) evaluated the effects of PGPR (mixture of Bacillus sp. B. subtillis, $B$ erythropolis, $B$. pumilus, and $P$. rubiacearum) 
on rhizosphere microbial activity and the growth of water celery in a field experiment. Results showed that the dry weight of water celery in the treatment with $50 \%$ organic compound fertilizer (OCF) with PGPR (PGPR $+1 / 2$ OCF) was increased by $34 \%$ compared with the treatment with $100 \%$ organic compound fertilizer added.

Numerous studies have shown the improvement in plant growth and development in response to seed or root inoculation with various microbial inoculants capable of producing plant growth regulators (Zahir et al., 2004). Trials with rhizosphere-associated plant growth-promoting $\mathrm{N}_{2}$-fixing and $\mathrm{P}$-solubilizing bacteria indicated yield increases in many crops such as wheat (Ozturk et al., 2003), barley (Cakmakci et al., 2001; Ozturk et al., 2003), sugar beet (Cakmakci et al., 2001), canola (de Freitas et al., 1997), and maize (Pal, 1998). Because of their spore-forming ability, plant growth-promoting strains are readily adaptable to commercial formulation and field application (Liu and Sinclair, 1993). The positive effects of Bacillus and Rhizobium on the yield and growth of crops such as chickpea, apple, strawberry, spinach, tomatoes, sugar beet, barley, and wheat were explained by $\mathrm{N}_{2}$-fixation ability, phosphate-solubilizing capacity, indole acetic acid, and antimicrobial substance production (Cakmakci et al., 2001, 2007; Elkoca et al., 2008; Esitken et al., 2010).

The effect of PGPR applications on chlorophyll readings in the study is in good agreement with the results of Yildirim et al. $(2008 \mathrm{a}, 2008 \mathrm{~b})$ in radish grown in saline conditions. PGPR treatments gave elevated reading values when compared with the non-inoculated controls in these studies. They proved that SPAD chlorophyll meter readings in leaves were correlated with tissue total $\mathrm{N}$ concentrations. This phenomenon might be caused by PGPR treatments with $\mathrm{N}_{2}$-fixing capabilities, promoting $\mathrm{N}$ uptake by plant roots.

In plants treated by PGPR with manure, the PNE concentration of leaves may provide important information about the effect of bacterial inoculation in PNE uptake. In this study, it was found that bacterial treatments increased PNE contents of broccoli plants compared with the control. Generally, the enhancements in macro-/micronutrient contents were more pronounced in PGPR treatments with manure, whereas mineral fertilizer also resulted in significant nutrient increases in plant leaf. Enhancement of mineral uptake by plants should result in an increased accumulation of minerals in leaves of the plant. The use of the $\mathrm{N}_{2}$-fixing and P-solubilizing PGPR in chickpea (Elkoca et al., 2008), barley (Cakmakci et al., 2007), tomato (Adesemoye et al., 2010), lettuce (Lai et al., 2008), and strawberry (Gunes et al., 2009) stimulated macro- and micronutrient uptake such as $\mathrm{N}$, $\mathrm{P}, \mathrm{K}, \mathrm{Ca}, \mathrm{Mg}, \mathrm{Fe}, \mathrm{Mn}, \mathrm{Zn}$, and $\mathrm{Cu}$, which were consistent with our results. On the other hand, the study results could suggest that PGPR application with manure could reduce over $50 \%$ the required $\mathrm{N}$ and $\mathrm{P}$ fertilizer to get the same yield with mineral fertilizer application. Bacterial inoculations with manure significantly also increased uptake of macronutrients and micronutrients by broccoli. Study results indicated that at least 50\% of chemical fertilizer could be saved when a PGPR application was used along with manure fertilizer.

The enhancement of $\mathrm{N}$ uptake by plants inoculated with the PGPR strains used in this study could be through associative $\mathrm{N}$ fixation based on the tests with $\mathrm{JNFb}$ medium. On the other hand, the PGPR have been reported to promote the growth of the plant and increase the root surface area or the general root architecture. Plants growing better in turn release higher amounts of carbon $(\mathrm{C})$ in root exudates. The release of more $\mathrm{C}$ prompts an increase in microbial activity, and this process continues in a cycle. The whole process makes more nutrients available from the soil pool, influencing nutrient flux into plant roots, and the plant is able to take up more available nutrients (Adesemoye et al., 2009).

\section{Conclusions}

The present study demonstrates that PGPR applications in addition to manure can be used to increase broccoli growth and yield without using mineral fertilizer. Efficient plant nutrition management should ensure both enhanced and sustainable agricultural production and safeguard the environment. Obviously, the use of chemical fertilizers and manures cannot be eliminated at this time without drastically decreasing food production. At the same time, the harmful environmental side effects of fertilizer use such as leaching, runoff, emission, and eutrophication of aquatic ecosystems worldwide cannot go unabated. Hence, there is an urgent need for integrated nutrient management that targets agricultural inputs and lowers the adverse environmental impacts of agricultural fertilizers and practices. Chemical, organic, or microbial fertilizer has its advantages and disadvantages in terms of nutrient supply, soil quality, and crop growth. So, developing a suitable nutrient management system that integrates use of these three kinds of fertilizers may be a challenge to reach the goal of sustainable agriculture. In view of environmental pollution in case of excessive use of mineral fertilizers and as a result of the high costs in the production of $\mathrm{N}$ and $\mathrm{P}$ fertilizers, bacteria tested in our study may well be suited to achieve sustainable and ecological agricultural broccoli production without decreasing yield compared with mineral fertilization application. An important nutritional problem of developing countries is micronutrient malnutrition, also called hidden hunger. Data may suggest that inoculations with PGPR have some potential to increase use efficiency of organic fertilizer in both organic and conventional farming.

In conclusion, Brevibacillus reuszeri and Rhizobium rubi were found to have great potential for use as PGPR to increase production in broccoli like in many other crops previously tested and to be used in development of biofertilizer needed for organic agricultural production because of rendering these insoluble phosphates into a soluble form and increasing organic matter mineralization through the process of acidification, chelation, and exchange reactions in plant growth media. Considering environmental pollution with excessive use of synthetic fertilizers and high costs in the production of $\mathrm{N}$ and $\mathrm{P}$ fertilizers, the bacteria tested in our study may be a promising alternative as a biofertilizer for vegetable production in sustainable and organic agricultural systems; however, much research is still needed.

\section{Literature Cited}

Adesemoye, A.O., H.A. Torbert, and J.W. Kloepper 2009. Plant growth-promoting rhizobacteria allow reduced application rates of chemical fertilizers. Microb. Ecol. 58:921-929.

Adesemoye, A.O., H.A. Torbert, and J.W. Kloepper. 2010. Increased plant uptake of nitrogen from $15 \mathrm{~N}$-depleted fertilizer using plant growthpromoting rhizobacteria. Appl. Soil Ecol. 46: $54-58$.

Alcantar, G., M. Sandoval, J.Z. Castellanos, F. Mendez, P. Sanchez, and M.N. Rodriguez. 2002. Plenary paper diagnostic methods to evaluate nutrient status of garlic, onion, and broccoli. Commun. Soil Sci. Plant Anal. 33:2585-2598.

AOAC. 2005. Official methods of analysis. 18th Ed. AOAC-Int., Arlington, VA.

Baligar, V.C., N.K. Fageria, and Z.L. He. 2001 Nutrient use efficiency in plants. Commun. Soil Sci. Plant Anal. 32:921-950.

Bashan, Y. and L.E. de-Bashan. 2005. Plant growth promoting, p. 103-115. In: Hillel, D. (ed.) Encyclopedia of soils in the environment Vol. 1. Elsevier Publication, Oxford, UK.

Bremner, J.M. 1996. Nitrogen total, p. 1085-1122. In: Sparks, D.L. (ed.). Methods of soil analysis. Part III. Chemical methods. 2nd Ed. America Society of Agronomy, Madison, WI.

Caballero-Mellado, J., J. Onofre-Lemus, P. Estradade los Santos, and L. Martı'nez-Aguilar. 2007. The tomato rhizosphere, an environment rich in nitrogen-fixing Burkholderia species with capabilities of interest for agriculture and bioremediation. Appl. Environ. Microbiol. 73:53085319.

Cakmakci, R., M.F. Donmez, and U. Erdogan. 2007. The effect of plant growth promoting rhizobacteria on barley seedling growth, nutrient uptake, some soil properties, and bacterial counts. Turk. J. Agr. For. 31:189-199.

Cakmakci, R., F. Kantar, and F. Sahin. 2001. Effect of N2-fixing bacterial inoculations on yield of sugar beet and barley. J. Plant Nutr. Soil Sci. 164:527-531.

de Freitas, J.R., M.R. Banerjee, and J.J. Germida. 1997. Phosphate-solubilizing rhizobacteria enhance the growth and yield but not phosphorus uptake of canola. Biol. Fertil. Soils 24:358364.

Elkoca, E., F. Kantar, and F. Sahin. 2008. Influence of nitrogen fixing and phosphorus solubilizing bacteria on the nodulation, plant growth, and yield of chickpea. J. Plant Nutr. 31:157-171.

Esitken, A., S. Ercisli, H. Karlidag, and F. Sahin. 2005. Potential use of plant growth promoting rhizobakteria (PGPR) in organic apricot production. International Conference on Environmentally Friendly Fruit Growing. Tartu, Estonia, 7-9 Sept. 2005. p. 90-97. 
Esitken, A., H.E. Yildiz, S. Ercisli, M.F. Donmez, M. Turan, and A. Gunes. 2010. Effects of plant growth promoting bacteria (PGPB) on yield, growth and nutrient contents of organically grown strawberry. Sci. Hort. 124:62-66.

Gunes, A., N. Atatoglu, M. Turan, A. Esitken, and Q.M. Ketterings. 2009. Effects of phosphatesolubilizing microorganisms on strawberry yield and nutrient concentrations. J. Plant Nutr. Soil Sci. 172:385-392.

Han, H.S. and K.D. Lee. 2005. Plant growth promoting rhizobacteria effect on antioxidant status, photosynthesis, mineral uptake and growth of lettuce under soil salinity. Res. J. Agr. Biological Sci. 1:210-215.

Hsieh, S.C. and C.F. Hsieh. 1990. The use of organic matter in crop production. Extension Bulletin No. 315, Food and Fertilizer Technology Center for the Asian and Pacific Region, Taipei.

Jones, T.A., D.C. Nielson, and J.R. Carlson. 1991. Development of a grazing-tolerant native grass for revegetating bluebunch wheatgrass sites. Rangelands 13:147-150.

Khan, W., B. Prithiviraj, and D.L. Smith. 2003. Photosynthetic responses of corn and soybean to foliar application of salicylates. Plant Physiol. 160:485-492.

Lai, W.-A., P.D. Rekha, A.B. Arun, and C.C. Young. 2008. Effect of mineral fertilizer, pig manure, and Azospirillum rugosum on growth and nutrient contents of Lactuca sativa L. Biol. Fertil. Soils 45:155-164.

Liu, Z.L. and J.B. Sinclair. 1993. Differentiation of intra specific groups within anastomosis group
I of Rhizoctonia solani species complex. Mycologia 85:797-800.

Mehta, S. and C.S. Nautiyal. 2001. An efficient method for qualitative screening of phosphatesolubilising bacteria. Curr. Microbiol. 43:51-56.

Mengel, K. and E.A. Kirkby. 1987. Principles of plant nutrition. IPI, Bern, Switzerland.

Mengel, K. and E.A. Kirkby. 2001. Principles of plant nutrition. 5th Ed., 635 pp. Kluwer Academic Publishers, Dordrecht, The Netherlands.

Mertens, D. 2005a. AOAC Official Method 922.02. Plants preparation of laboratory sample. Official methods of analysis. 18th Ed. Horwitz, W. and G.W. Latimer (eds.). Chapter 3, p. 1-2. AOAC-International, Gaitherburg, MD.

Mertens, D. 2005b. AOAC Official Method 975.03. Metal in plants and pet foods. Official methods of analysi. 18th Ed. Horwitz, W. and G.W. Latimer (eds.). Chapter 3, p. 3-4. AOACInternational, Gaitherburg, MD.

Neufeld, H., A.H. Chappelka, G.L. Somers, K.O Burkey, A.W. Davison, and P. Finkelstein. 2006. Visible foliar injury caused by ozone alters the relationship between SPAD meter readings and chlorophyll concentrations in cut leaf coneflower. Photosynth. Res. 87:281-286.

Ozturk, A., O. Caglar, and F. Sahin. 2003. Yield response of wheat and barley to inoculation of plant growth promoting rhizobacteria at various levels of nitrogen fertilization. J. Plant Nutr. Soil Sci. 166:1-5.

$\mathrm{Pal}$, S.S. 1998. Interaction of an acid tolerant strain of phosphate solubilizing bacteria with a few acid tolerant crops. Plant Soil 198:169-177.
Roberts, T.L. 2008. Improving nutrient use efficiency. Turk. J. Agr. For. 32:177-182.

SPSS Inc. 2010. SPSS Inc. SPSS ${ }^{\circledR} 18.0$ base user’s guide. Prentice Hall, IL.

Yildirim, E., M.F. Donmez, and M. Turan. 2008a. Use of bioinoculants in ameliorative effects on radish (Raphanus sativus L.) plants under salinity stress. J. Plant Nutr. 31:20592074.

Yildirim, E., M. Turan, and M.F. Donmez. 2008b. Mitigation of salt stress in radish (Raphanus sativus L.) by plant growth promoting rhizobacteria. Roman Biotech Let. 13:3933-3943.

Young, C.C., W.A. Lai, F.T. Shen, W.S. Huang, and A.B. Arun. 2004. Characterization of multifunctional biofertilizer from Taiwan and biosafety considerations. International Symposium on $\mathrm{Fu}-$ ture Development of Agricultural Biotechnology Park. The symposium series for celebrating the establishment of the Agricultural Biotechnology Park, Council of Agriculture, Executive Yuan, and the 80th Anniversary of National Pingtung University of Science and Technology. p. 373-388.

Young, C.C., W.A. Lai, F.T. Shen, M.H. Hung, W.S. Hung, and A.B. Arun. 2003. Exploring the microbial potentially to augment soil fertility in Taiwan. Proc. of the 6th ESAFS International Conference: Soil Management Technology on Low Productivity and Degraded Soils, Taipei, Taiwan, p. 25-27.

Zahir, A., Z.M. Arshad, and W.F. Frankenberger. 2004. Plant growth promoting rhizobacteria. Adv. Agron. 81:97-168. 